International Journal of Social Sciences and Humanities
Available online at http://sciencescholar.us/journal/index.php/ijssh
Vol. 3 No. 3, December 2019, pages: 117 127
e-ISSN: 2550-7001, p-ISSN: 2550-701X
https://doi.org/10.29332/ijssh.v3n3.359

\title{
Economic, Social and Cultural Changes in Society Due to Sustainable Tourism Development
}

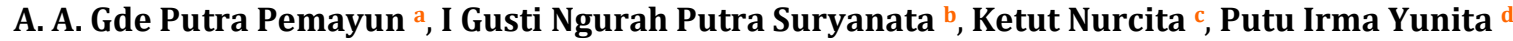

Article history: Received 27 April 2019, Accepted: 31 August 2019, Published: 23 November 2019

\section{Correspondence Author ${ }^{\text {a }}$}

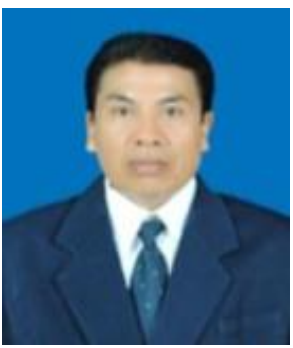

\section{Keywords}

environmental change; expansion of tourism; globalization; social and cultural; tourism development;

\begin{abstract}
This study examines the changes in the economic, social and cultural community due to sustainable tourism development in the Kutuh Petulu Village Ubud Bali. The advancement of technology and information is very fast causing all components of life to change both the values and culture of society with the rapid modernization in all fields causing changes in the economic, social and cultural, lifestyle that is very dynamic. The problem in this study: How are the economic, social and cultural changes of the community due to sustainable tourism development in the Kutuh Petulu Village of Ubud Bali. The purpose of this study: to understand and describe the meaning and form of environmental, economic, social and cultural changes due to sustainable tourism development in Kutuh Village Ubud, Bali. This study uses a descriptive qualitative method, using proportional sampling techniques consisting of managers of Villas and Hotels as well as people who work in the tourism sector in the Kutuh Petulu Village, Ubud, Bali. Sustainable tourism development is an effort by the government and the community to create jobs for future generations so that Bali's Groos Domestic Product is increasing given the enormity of globalization.
\end{abstract}

e-ISSN: 2550-7001, $p$-ISSN: 2550-701X ${ }^{\odot}$ Copyright 2019. The Author SS Journals Published by Universidad Técnica de Manabí. This is an open-access article under the CC BY-SA 4.0 license (https://creativecommons.org/licenses/by-sa/4.0/) All rights reserved.

\section{Contents}

Abstract

1. Introduction 118

2. Materials and Methods 119

3. Results and Discussions

4. Conclusion

a Universitas Pendidikan Nasional, Denpasar, Indonesia

b Universitas Pendidikan Nasional, Denpasar, Indonesia

c Universitas Pendidikan Nasional, Denpasar, Indonesia

d Universitas Pendidikan Nasional, Denpasar, Indonesia 


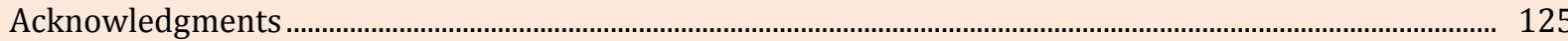

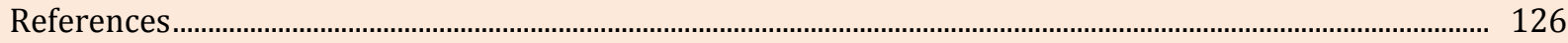

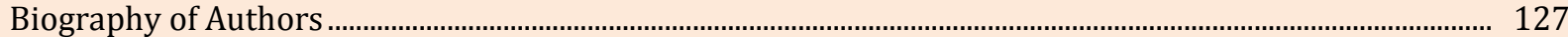

\section{Introduction}

Tourism development began to be felt, namely the economic rate that began to increase. The tourism sector has become one of the cornerstones of the people of Ubud in improving their standard of living and this must be fought continuously. This is the importance of the realization of sustainable tourism development cannot be denied, the development of the tourism sector does bring employment to the community, this is then expected to improve the quality of life of the people (Amerta et al., 2018; Wisudawati \& Maheswari, 2018). This must be considered, be aware that the tourism sector can bring in a lot of jobs, business opportunities and increased regional income. Since 2017, it is considered as an important moment to celebrate international tourism day. The UN World Tourism Organization (UNWTO), the UN agency in charge of the tourism sector, even predicted in 2017 as the "International Year of Sustainable Tourism for Development". This campaign is echoed as support for the United Nations Sustainable Development Goals program campaign. Since the beginning of the year, the United Nations has been working to increase global public awareness for tourism and change tourism as a catalyst for change in a more positive direction. With the establishment of tourism as one of the leading sectors of the national economy by targeting 20 million tourists with an estimated income of around Rp. 260 trillion, the Minister of Tourism on several occasions often said that "Tourism is the future of Indonesia". The statement then leads to the question, then, how the role of tourism in contributing to improving welfare. This is the most important study because up to now the society is still constrained by various kinds of stumbling problems such as improving education, mastering technology, improving human resources, improving people's economy and finally improving public health as an indicator that a country has succeeded in following a neighboring country who went first. The main problems in this study are:

a) How is the economic, social, and cultural changes of the community due to sustainable tourism development in the Kutuh Petulu Village of Ubud Bali?

b) How can sustainable tourism development create jobs for Balinese?

\section{Literature Review}

Some of the results of studies that have been conducted that are relevant and can be used as a reference in this study can be stated as follows. Based on research studies about Ubud more focused on the problem of painting and tourism.

Research Picard et al., (2006), entitled "Cultural Tourism and Cultural Tourism" (Case Study of Ubud). The results of this study indicate that the Ubud area attracts tourists who want to see Bali in its artistic image and ceremony. The results of the discussion showed that tourists wanted to see the original Balinese village. Every day Ubud is flooded with hundreds of tourists who specifically come from Nusa Dua, Sanur, and Kuta to see the painter's village. In addition, many visitors to learn the arts that have become a source of fame in the village of Ubud, namely dance, sculpture, and painting. In conclusion, the focus of this study describes the development of tourism and the increasing number of local artists interested in pursuing the heritage of their ancestors to remain sustainable. Also many foreign tourists learn to dance traditional dances and communities have even formed several dance and gambling groups in several countries.

Further research Brata et al., (2012), titled "Commodification of Telegraphs in the Globalization Era in Ubud Village, Ubud District, Gianyar Regency." This study raises the reality that occurs in the field relating to the problem of utilizing telecommunications which are one of the traditional open spaces into a place of business. The swift influence of global culture entering the Ubud region has implications for the occurrence of capitalist ideological practices within the framework of the tourism industry, such as the emergence of the culture industry, popular culture, lifestyle, and consumerism culture (Sumadi, 2016; Indiani \& Suda, 2018).

Telancing as one of the traditional open spaces experiences commodification, commercialization, and tourism as an adaptive form following the tastes of tourists as global cultural representations that produce new forms and meanings. The discussion shows that globalization has resulted in the teleportation function 
which is one of the characteristics of traditional open spatial identity with the values contained in it being lost, road space is narrow, and congestion. The commodification of telecommunications in the era of globalization is defined as how it is produced, distributed and consumed by the market. The conclusion is that telecommunications are commercialized, traded like goods and services (traded) or commodified in various forms or displays of economic spaces. Based on the description and discussion of the two studies above that this study is different in terms of the parameters used and the results of the discussion.

\section{Materials and Methods}

\section{Data Types and Sources}

The data used in this study are:

a) Primary data, i.e. data and information obtained directly from sources/respondents. This data was obtained by conducting interviews with several Village officials and tourism workers in the Kutuh Petulu Village of Ubud. By using proportional sampling technique with a sample of 3 kelian banjar, 2 kelian kelang, and 22 tourism workers.

b) Secondary data, namely supporting data and information obtained from the Office of Kutuh Petulu Village Ubud, Bali.

\section{Research model specifications}

Harrod-Domar's Economic Growth Theory in Jima et al., (1983). Economic growth is determined by high savings and investment. If savings and investment are low, then the economic growth of the community or country is also low. This can be found in developed and developing countries, people in developed countries are people who have high investment which is realized in shares, danareksa, indices, and other forms of investment. The assumption underlying this theory is that the problem of development is basically a matter of capital investment (Hepsiba et al., 2016; Anita et al., 2018). If capital investment has developed well, then the country's economic development will also develop well. Thus, one of the implications in the development of the Kutuh Petulu Village in Ubud, Bali, is that the government encourages investment in investment and makes investment flourish in Bali. The Indonesian government rests on the theory of Harrod-Domar, to create an institution namely the National Investment because this step is considered a strategic step for economic growth and development (Iswanto et al., 2018; Saravanadurai \& Manimehalai, 2016). Development requires structural transformation in all aspects of life, both cultural, political, social, economic and other changes. Theories that are built related to development are very closely related to development strategies. Development theory contains various social science approaches that attempt to deal with the problem of underdevelopment.

The Theory of Social and Cultural Change Karl Max (1961). The theory of social and cultural change is a natural thing and will continue as long as humans interact and socialize. Social changes and cultural changes occur because of changes in elements in people's lives, both material and immaterial, as a way of maintaining the balance of the people of Kutuh Petulu Ubud and adjusting to the development of dynamic times. For example, geographic, biological, economic, or cultural elements. Social change is the main social condition that causes social change (Brata \& Pemayun, 2018; Jurgaitis, 2018). These conditions include economic, technological, geographical or biological conditions. This condition causes changes in other aspects of social life. Social change has a clear direction through the Kutuh Petulu Ubud community. All societies go through the same phase sequence and start from the initial development stage to the last development. When the final stage has been reached, the evolutionary change has ended. The most important principle of the theory of evolution is that the stages of society originate from birth, growth, and perfection (Anike et al., 2017; Haque, 2015). Durkheim argues that evolutionary change influences the way people regulate, especially with respect to work. Meanwhile, according to Tonnies, people change from a simple society with close and cooperative relations, to a large type of society with special and impersonal relationships.

Pemayun, A. A. G. P., Suryanata, I. G. N. P., Nurcita, I. K., \& Yunita, P. I. (2019). Economic, social and cultural changes in society due to sustainable tourism development. International Journal of Social Sciences and Humanities, 3(3), 117-127. https://doi.org/10.29332/ijssh.v3n3.359 
Research location

The location of this research is in Kutuh Petulu Village, Ubud Bali, by observing and mapping measurable community activities. The observation time as the object of analysis is the condition of 9 (nine) months from January to September running in 2019. consideration of the use of 2019 was taken to facilitate the recording of information on respondents, namely, kelian banjar, kelian adat, and tourism workers in the Kutuh Petulu Village, Ubud Bali, Bali.

\section{Research instruments}

The instrument used in this research is descriptive research through literature surveys and field surveys and in-depth interviews. Interviews conducted are open-ended questions and closed-ended questions.

\section{Data analysis method}

The analytical method used in this study includes several methods in accordance with the objectives of the study are as follows:

Harrod-Domar's Economic Growth Theory in Guma (1967). Different economic growth and significant differences in income distribution patterns in various countries in the world are phenomena that are not too easy for economists to explain. In general, there are three issues that are most frequently discussed and interrelated in the problem of growth, namely: world growth, country growth, and the inequality of income level. As economic growth becomes more complex, economists have tried to develop various growth models that try to explain why some countries are rich and some are poor. However, until now there has been no model of economic growth that is truly powerful in explaining the factors that drive economic growth itself without making simplifications through unrealistic assumptions in the real world. For example, why can East Asian countries experience rapid growth (Asian Miracles) compared to other countries in the past three decades? Why Germany and Japan could rise and experience better economic growth after World War II ended.

A more extreme case is why countries in Africa have never been free from the problem of prolonged poverty. Various approaches are used to analyze and obtain better results regarding factors that affect growth. The consumption and investment sides are most often discussed. The linkages of the most basic factors of production such as the amount of capital, the number of workers, and technological progress are also involved in the analysis but in reality, not all cases of economic growth experienced by various countries can be explained with the same growth model. In this case, the Harrod-Domar economic growth model is examined by prioritizing Saving Rates and Growth. It revealed the relationship between saving rate and economic growth with 3 focus of study: first, is trying to reveal the source of economic growth and see what positive effects can be caused by an exogenous variable named saving rate to the level of income and growth. Second is trying to find what factors are determinants for the creation of a saving rate that supports growth. Third, is to find out the causal relationship between saving rate and growth. Harrod-Domar's economic growth model places saving as a major factor in shaping economic growth. Economic growth in this model depends on marginal propensity to save and capital-out ratio.

Karl Max Theory of Social and Cultural Change (1961). The theory of social and cultural change is a natural thing and will continue as long as humans interact and socialize. Social changes and cultural changes occur because of changes in elements in people's lives, both material and immaterial, as a way of maintaining the balance of the people of Kutuh Petulu Ubud and adjusting to the development of dynamic times. For example, geographic, biological, economic, or cultural elements. Social change is the main social condition that causes social change. These conditions include economic, technological, geographical or biological conditions. This condition causes changes in other aspects of social life. Social change has a clear direction through the Kutuh Petulu Ubud community.

All societies go through the same phase sequence and start from the initial development stage to the last development. When the final stage has been reached, the evolutionary change has ended. The most important principle of the theory of evolution is that the stages of society originate from birth, growth, and perfection. Durkheim argues that evolutionary change influences the way people regulate, especially with respect to 
work. Meanwhile, according to Tonnies, people change from a simple society with close and cooperative relations, to a large type of society with special and impersonal relationships. This change always continues to be seen from the division within the Kutuh Petulu Ubud community, individuals become alienated, as well as socio-cultural changes to individualization and the search for power.

These symptoms have struck the people of the Kutuh Petulu Village Ubud. Besides that, Paul B. Horton (1999) states that there are a number of weaknesses in the Theory of Evolution including the following. (1) Data that support the determination of stages in the community into a series of stages that are often not careful. It can be concluded that the stages of the development of the Kutuh Petulu Ubud community are determined according to the stages that are most in accordance with this theory. (2) The sequence in the development stage is not entirely assertive, because there are a number of Kutuh Petulu Ubud communities that are able to go beyond a certain stage and go directly to the next stage, in other words passing through one stage. In contrast with before, there are also groups of people who just walk backward, not going forward as they wish. (3) His view that social change will end at its peak when the people of Kutuh Petulu Ubud have prospered.

\section{Observation Techniques, Interviews, Documentation Studies}

Observation is carried out by making direct observations in the field so that they can see and observe more closely about the condition of the Kutuh Village Ubud, Bali. In-depth interviews (Indept Interview) with 27 informants. Documentation studies, namely data collection techniques by taking a number of documents or past records at the village office or relevant agencies.

\section{Results and Discussions}

Harrod-Domar's Economic Growth Theory in Guma (1967). Harrod-Domar's theory is an extension of Keynes's analysis of national economic activity and the problem of labor use. Keynes's analysis is considered incomplete because it does not address the problem of overcoming long-term economic problems. The analysis made by Harrod and Domar aims to cover up this weakness. The theory ultimately analyzes the following problem: "What conditions or conditions are created in the economy to ensure that from time to time the ability to produce which always increases as a result of the investment will always be fully used? In other words, the Harrod-Domar theory essentially tries to show the conditions needed for steady growth which is defined as growth that will always create the full use of capital tools that will always apply in the economy in the Kutuh Petulu Village, Ubud, Bali. Harrod and Domar maintained the opinion of previous economists who emphasized the role of capital formation in creating economic growth. But in contrast to the views of the Classics and Keynes, who paid attention to only one aspect of capital formation, Harrod-Domar's theory emphasized both aspects of capital formation, in the opinion of the Classics capital formation is an expenditure that will add to the capability of the people of the Kutuh Village Petulu Ubud Bali to increase production.

For the classics of capital formation is an expenditure that will increase the number of capital tools in the community of Kutuh Petulu Ubud. If this capacity increases, naturally national production and income will increase and economic development will be created. This situation will occur because "Supply creates its own demand" means that the increase in capital tools in the Kutuh Petulu Ubud community of Bali will automatically create an increase in national production and economic development. Because of this belief the classics did not pay attention, to the second function of capital formation in the economy, namely to increase the level of expenditure in the Kutuh Petulu Ubud community. In Harrod-Domar's theory, capital formation is seen as an expenditure that will increase the ability of an economy to produce goods, and as an expenditure that will increase the effective demand of the entire community of Kutuh Petulu Village, Ubud.

The theory shows a fact that is ignored in Keynes's analysis, namely, if a certain period of time number of capital formation is carried out, then in the next period, the economy has a greater ability to produce goods from the Kutuh Petulu Village Ubud Bali Bali. Besides that, in accordance with Keynes's opinion, HarrodDomar's theory also considers that this increase in production capability does not automatically create an increase in production and an increase in national income. Domar considers investment to play a key role in

Pemayun, A. A. G. P., Suryanata, I. G. N. P., Nurcita, I. K., \& Yunita, P. I. (2019). Economic, social and cultural changes in society due to sustainable tourism development. International Journal of Social Sciences and Humanities, 
the growth process and puts pressure on its dual characteristics. But Harrod considers the level of income as the most important factor in the growth process. While Domar is in a relationship between supply and demand for investment, Harrod, on the other hand, equates demand and supply of savings. The Harrod-Domar theory is one theory that continues to be used and continues to be developed. This can be found in developed and developing countries.

The Harrod-Domar theory is one theory that continues to be used and continues to be developed. This can be found in developed and developing countries, people in developed countries are people who have a high investment which is realized in shares, danareksa, indices, and other forms of investment. The closest example can be seen how Singaporeans have a high level of investment compared to other countries in Southeast Asia. The assumption underlying this theory is that the problem of development is basically a matter of capital investment. If capital investment has developed well, then economic development in the Kutuh Village of Ubud, Bali will also flourish. Thus, one of the implications in the development of Kutuh Petulu Ubud in particular and Bali in general, the government encourages investment in investment and makes investment flourish in the Kutuh Petulu Village Ubud. The Bali government rests on the theory of Harrod-Domar, to create an institution namely the National Investment because this step is considered a strategic step for the growth and development of the Balinese economy.

In this context, the availability of capital to create social and economic sectors in the Kutuh Petulu Village, Ubud, Bali is a challenge for the local government to be thoroughly examined by looking at the fact that ASEAN neighboring countries such as Malaysia, Thailand, and Philippines are far more advanced compared to Indonesia, both economically and by increasing human resources. . Associated with social and economics, a large investment in the tourism sector and infrastructure to support access to travel requires a very large investment. Diversity of people from ethnic, cultural, educational level and others, requires an approach and involvement that embraces all elements.

Of course, this requires more intensive participation from the people of the Kutuh Petulu Village Ubud and the people of Bali. This success will become a forum for all parties who have the same concern. Social and economic changes in the community of Kutuh Petulu Ubud will be carried out various studies and discussions with various groups to find alternative solutions to various social and economic problems being faced. This strategy is expected to be a partner for the government, intellectuals and business people, to provide better policy alternatives for the interests of the Kutuh Petulu Village of Ubud and Bali in general. In addition, Solow's Theory and Economic growth model as one of the models of economic growth provides static analysis of how the relationship between capital accumulation, population growth, and technological development as well as the influence of the three on the level of output production. This model provides answers to the question why the economy in one region can grow faster than economic growth in other regions.

The Solow model shows that the saving rate is an important determinant of the capital stock under steadystate conditions. In other words, if the saving rate is high, then the economy will have large capital stock and a high level of output, and vice versa. The basis of the Solow model is then much associated with fiscal policy. The ongoing budget deficit can reduce savings and reduce the ability to invest in Kutuh Petulu Village Ubud. In relation to the growth rate, according to Solow, a higher saving rate will only temporarily increase growth until the economy reaches a new steady-state condition that is higher than before in the Kutuh Petulu Village of Ubud. If the economy maintains a high level of saving, then it will only maintain a large capital stock and a high level of output without maintaining a high rate of growth.

Based on the description above it can be concluded that the assumptions underlying the Harrod-Domar theory namely the problem of development are basically a matter of capital investment. If the capital investment has developed well, then the economic development of the Kutuh Petulu Village Ubud will also develop well. Thus, one of the implications for development in the Kutuh Petulu Village of Ubud and Bali in general, the government encourages investment in investment and makes investment thrive in the Kutuh Petulu Village of Ubud. The Bali government rests on Harrod-Domar's theory until the central government establishes an institution namely the National Investment because this step is considered a strategic step for economic growth and development in the Kutuh Petulu Village, Ubud.

In this context, social and economic changes occur considering the swift development of tourism and globalization which is difficult to predict. The challenges of the local and central government of Bali to be carefully examined with the rapid development of ASEAN countries such as Malaysia, Thailand and the Philippines are far more advanced compared to Bali and Indonesia in terms of both economy and human 
resource development. Large investment in the Kutuh Petulu Village Ubud to build facilities and infrastructure to support access to the flow of goods and services quickly to the destination. The diversity of the Kutuh Petulu Ubud community from ethnic, cultural, educational level and others, requires an approach and involvement that embraces all elements. Of course this requires more intensive participation from the people of the Kutuh Petulu Village Ubud and the people of Bali.

Karl Max Theory of Social and Cultural Change in (1961). The theory of social and cultural change is a natural thing and will continue as long as humans interact and socialize. Social changes and cultural changes occur because of changes in elements in people's lives, both material and immaterial, as a way of maintaining the balance of the people of Kutuh Petulu Ubud and adjusting to the development of dynamic times. For example, geographic, biological, economic, or cultural elements. Social change is the main social condition that causes social change. These conditions include economic, technological, geographical or biological conditions. This condition causes changes in other aspects of social life. Social change has a clear direction through the Kutuh Petulu Ubud community.

All societies go through the same phase sequence and start from the initial development stage to the last development. When the final stage has been reached, the evolutionary change has ended. The most important principle of the theory of evolution is that the stages of society originate from birth, growth, and perfection. Durkheim argues that evolutionary change influences the way people regulate, especially with respect to work. Meanwhile, according to Tonnies, people change from a simple society with close and cooperative relations, to a large type of society with special and impersonal relationships. This change always continues to be seen from the division within the Kutuh Petulu Ubud community, individuals become alienated, as well as socio-cultural changes to individualization and the search for power. These symptoms have struck the people of the Kutuh Petulu Village Ubud.

Besides that, Paul B. Horton (2007), states that there are a number of weaknesses in the Theory of Evolution including the following. (1) Data that support the determination of stages in the community into a series of stages that are often not careful. It can be concluded that the stages of the development of the Kutuh Petulu Ubud community are determined according to the stages that are most in accordance with this theory. (2) The sequence in the development stage is not entirely assertive, because there are a number of Kutuh Petulu Ubud communities that are able to go beyond a certain stage and go directly to the next stage, in other words passing through one stage. In contrast with before, there are also groups of people who just walk backward, not going forward as they wish. (3) His view that social change will end at its peak when the people of Kutuh Petulu Ubud have prospered. Whereas conflict theory explains that conflict originates from class disputes between groups that control capital or government with materially oppressed groups, thus leading to social change.

The most important source of social change in this perspective is social class conflict in the Kutuh Petulu Ubud community. This perspective has the principle that social conflict and social change are things that are always attached to the structure of the Kutuh Petulu Ubud community. This theory is based on Karl Marx's thought that social class conflict is the most important and influential source of all social change. Furthermore, Functional Theory assumes that every element of the community of Kutuh Petulu Ubud gives functions to other elements of society. Changes that occur in the Klutuh Petulu Ubud community will also cause changes in other parts. The concept of culture shock is explained by social change within a functional framework, although elements of the Kutuh Petulu Ubud Bali community are interconnected with one another, some elements can change very quickly, while others do not. Such delays create social and cultural divisions between rapidly changing elements and slow elements. This gap will cause social and cultural shock to the people of Kutuh Petulu Ubud.

The last one, Cycle Theory, has an interesting perspective in seeing social change because it assumes that social change cannot be fully controlled by anyone, even skilled people. In every Kutuh Petulu Ubud community, there are cycles that must be followed. The rise and decline of civilization (culture) are inevitable and social change is not always good.

From the discussion above it can be concluded that each community of Kutuh Petulu Ubud evolved through four stages of development such as human growth, namely childhood, adolescence, adulthood, old age. Based on the description above it can be said that the most important source of social change in this perspective is social class conflict in the Kutuh Petulu Ubud community. Social conflict and social change are things that are always attached to the structure of the people of Kutuh Petulu Ubud. This theory is based on

Pemayun, A. A. G. P., Suryanata, I. G. N. P., Nurcita, I. K., \& Yunita, P. I. (2019). Economic, social and cultural changes in society due to sustainable tourism development. International Journal of Social Sciences and Humanities, 3(3), 117-127. https://doi.org/10.29332/ijssh.v3n3.359 
Karl Marx's thought that social class conflict is the most important and influential source of all social changes in the Kutuh Petulu Village Ubud. Social change assumes that social change cannot be fully controlled by anyone, even skilled people.

In implementing social and cultural changes, the people of Kutuh Petulu Ubud Village can be informed as follows: (1) Kinship System, The principle of the descendants of the people of Ubud, especially those who are Hindu, based on patrilineal principles, namely kinship relations through men or referred to by the term purusa. This results in that for every individual in the Kutuh Petulu Ubud community all his father's relatives fall within the boundaries of his kinship. Such a pattern applies in the case of inheritance, whereas in other aspects of life such as attending prayers in a family-owned temple (pura dadie or paibon) it is permissible for men even though it is done in the temple dadia of the mother and wife's family environment. As with the Balinese community in general, in the Kutuh Petulu Ubud community, there are three kinds of kinship groups. The smallest group is called the nuclear family which in the Kutuh Petulu Ubud community is called paon or roban or also called pekurenan.

According to Bagus (1979) the formation of this kinship group as a result of marriage was formed in the community of Kutuh Petulu Ubud Bali, a kinship group which is an economic unit that lives from one kitchen (paon). This social unity in Bali is called family or pekurenan, which can be simple, consisting of parents and unmarried children and can be more complex, consisting of more than one wife (polygamy) with their children unmarried. Usually this wife's family lives in one housing estate and is separated only by occupying buildings (bale) only. The second kinship group in the larger Kutuh Petulu Ubud community is a form of carving. This kinship group is the same as what Koentjaraningrat refers to as a virilocal extended family (Danandjaya, 1987).

This kinship group lives together in a housing estate consisting of several nuclear families, also known as extended families (Bagus, 1979). The kinship group, called carving or rock, in addition to being made up of several families also lives in a single building that is usually marked or bounded by a sliding wall. In relation to the yard and the settled system of the Kutuh Petulu Ubud community, it is not only related to the community system. For the people of Kutuh Petulu Ubud, the plots of land they occupy are divided into two parts, namely the village plots where the plots of land belonging to the village and the second is the plots of land outside the main village which are generally private property of each family occupying the plots. Usually the private property is called a fertility reef and the village property is called a village reef. Furthermore, the third-largest kinship group is dadia. This group can be likened to what Koentjaraningrat calls minimal lineage (Danadjaya, 2009).

This dadia is a group of kinship consisting of a combination of households (kinship of corals) who feel they are from one ancestor and are bound to one another through only male lineage. In the Kutuh Petulu Village Ubud there are quite a number of kinship groups of dadia or apaibon whose citizens average between five and one hundred and twenty households.

\section{Conclusion}

First, the development of sustainable tourism in the Kutuh Petulu Village Ubud, Bali, towards economic development, including the creation of jobs, sources of foreign exchange and the distribution of spiritual development. Conversely, the negative influence of tourism, namely (1) Easily subject to economic attacks (vulnerability) means that the tourism sector is very sensitive to the occurrence of world political and economic fluctuations. (2) There is a time allocation for the tourism sector, namely low season and high season or low season and crowded season. (3) The development of tourism causes the conversion of agricultural land into Villas, Restaurants, Hotels and other tourism facilities.

Second, the development of the tourism sector affects the social and cultural life of the people due to global touristification. The social and cultural life of the people of Kutuh Petulu Village in Ubud is due to the swift influences of tourists who come into direct contact with the way they dress, patterns of life that mimic western styles. In terms of culture, many sacred dances have become provan because the insistence of foreign tour operator operators wants sales of tour destinations to increase in accordance with the progress of the western economy. 
Findings

The development of sustainable tourism can expand employment opportunities for young people both in rural and urban areas. Tourism is very sensitive to global economic and political development which is difficult to predict. Therefore, it must be prepared early to overcome it more quickly.

\section{Acknowledgments}

The authors would like to thank the editor of IJSSH for their valuable time, support and advice in completing the current study.

Pemayun, A. A. G. P., Suryanata, I. G. N. P., Nurcita, I. K., \& Yunita, P. I. (2019). Economic, social and cultural changes in society due to sustainable tourism development. International Journal of Social Sciences and Humanities, 3(3), 117-127. https://doi.org/10.29332/ijssh.v3n3.359 


\section{References}

Amerta, I. M. S., Sara, I. M., \& Bagiada, K. (2018). Sustainable tourism development. International Research Journal of Management, IT and Social Sciences, 5(2), 248-254.

Anike, H. O. O., Okafor, C. N., \& Udejinta, N. B. (2017). The role of public enterprises in economic development in Nigeria. International Research Journal of Management, IT and Social Sciences, 4(2), 179-189.

Anita, D., Mbete, A. M., \& Mandala, H. (2018). Ecolexicon wealth of nautical expression in Kuta Lombok society. International Research Journal of Engineering, IT \& Scientific Research, 4(3), 17-22. https://doi.org/10.21744/irjeis.v4n3.244

Bagus, I. G. N. (1979). Perubahan pemakaian bentuk hormat dalam masyarakat Bali sebuah pendekatan etnorafi berbahasa.

Brata, I. B. (2012). Komodifikasi Telajakan dalam Era Globalisasi di Ubud Kecamatan Ubud Kabupaten Gianyar (Disertasi). Denpasar: Pascasarjana Universitas Udayana.

Brata, I. B., \& Pemayun, A. G. P. (2018). Human Resource Competency Tourism Bali together with ASEAN Economic Community. International Research Journal of Management, IT and Social Sciences, 5(2), 186194.

Danandjaya, J. (1987). Manfaat Media Tradisional untuk Pembangunan. Kebudayaan dan Pembangunan: Sebuah Pendekatan.

Guma, S. M. (1967). The form, content and technique of traditional literature in Southern Sotho. Pretoria: van Schaik.

Haque, Z. (2015). The impact of economic crisis on tourism industry. International Research Journal of Engineering, IT \& Scientific Research, 1(1), 12-23.

Hepsiba, N., Subhashini, A., Raju, M., \& Rao, Y. P. (2016). Changing role of teachers in the present society. International Research Journal of Engineering, IT \& Scientific Research, 2(9), 67-72.

Horton, P. B., Hunt, C. L., \& Ram, A. (1999). Sosiologi. Penerbit Erlangga.

Indiani, N. M., \& Suda, I. K. (2018). Interpret Ogoh-ogoh towards Hindu Contemporary Society. International Research Journal of Management, IT and Social Sciences, 5(1), 65-71.

Iswanto, -, Riana, I. K., Simpen, I. W., \& Ola, S. S. (2018). Supernatural signification system amuf on death ritual speech nen fen nahat neu nitu in boti society. International Journal of Linguistics, Literature and Culture, 4(2), 46-57.

Jima, K., Ando, K., Kishi, M., Nakashizuka, T., \& Hayakawa, T. (1983). Collagenase activity in human saliva. Journal of dental research, 62(6), 709-712. https://doi.org/10.1177\%2F00220345830620060301

Jurgaitis, N. (2018). Economic crisis as a supernatural being in public discourse. International Journal of Linguistics, Literature and Culture, 4(2), 66-71.

Max, K. (1961). Selected writing in sociology and social philosophy (No. HN28 M3).

Picard, D. (2006). Festivals, tourism and social change: Remaking worlds. Channel view publications.

Saravanadurai, A., \& Manimehalai, N. (2016). Primary agricultural credit societies in India. International Research Journal of Engineering, IT \& Scientific Research, 2(7), 51-61.

Sumadi, K. (2016). Tourism development basis in traditional village of Kuta. International Journal of Linguistics, Literature and Culture, 2(3), 124-132.

Wisudawati, N. N. S., \& Maheswari, A. I. A. (2018). Potential of Silver Craft Product through to CommunityBased for Tourism Sustainability in Celuk Village. International Research Journal of Management, IT and Social Sciences, 5(1), 9-15. 


\section{Biography of Authors}

\begin{tabular}{|l|l||}
\hline & $\begin{array}{l}\text { Dr. Drs. A. A. Gde Putra Pemayun, M.Si. is an associate professor in the Department } \\
\text { of Economics, Faculty of Economics Undiknas University of Denpasar, Indonesia. } \\
\text { Address: Jalan Bedugul No. 39 Denpasar, Bali Province, Indonesia, Post Code } \\
\text { (3261) 723868. Phone: +62) 82145997234. Education background: Bachelor } \\
\text { degree: A graduation at the Faculty of Economic in Undiknas in 1985. Master } \\
\text { degree: A graduation at the Postgraduate Program in Unud, Cultures and Art } \\
\text { Studies Program in 2003. Ph.D. degree: A graduation at the Doctorate Program in } \\
\text { Unud, Cultures and Art Studies Program in 2014. } \\
\text { Email: putra.pemayun@gmail.com }\end{array}$ \\
\hline & $\begin{array}{l}\text { Dr. Drs. I Gusti Ngurah Putra Suryanata, MS. is an associate professor. He was born } \\
\text { in Denpasar, July 29th, 1956. He graduated his bachelor degree in 1985 at } \\
\text { Universitas Pendidikan Nasional Denpasar. He finished his master degree in 1987 } \\
\text { at Universitas Gadjah Mada. He completed his doctoral degree in 2009 at } \\
\text { Universitas 17 Agustus 1945. He lives at Jalan Palapa XIII Nomor 5, Ph. } \\
\text { +6281337253041. His office address at Jalan Bedugul No. 39 Sidakarya, Denpasar, } \\
\text { Indonesia. } \\
\text { E-mail address: ngurahputrasuryanata@undiknas.ac.id }\end{array}$ \\
\hline $\begin{array}{l}\text { Drs. I Ketut Nurcita, MM., is an associate professor in Universitas Pendidikan } \\
\text { Nasional, Denpasar, Indonesia. He was born in Gianyar, 30 July 1957. He } \\
\text { graduated bachelor degree in Universitas Pendidikan Nasional, Denpasar, } \\
\text { Indonesia. He finished master degree in Universitas Pendidikan Nasional, } \\
\text { Denpasar, Indonesia. He currently lives at Sukawati Village, Gianyar Regency, Bali } \\
\text { Province, Indonesia. } \\
\text { Email: ketutnurcita@undiknas.ac.id }\end{array}$ \\
$\begin{array}{l}\text { Putu Irma Yunita, SE., MSc., was born on June 22nd, 1988 in Denpasar. She is a } \\
\text { lecturer at Undiknas University, Denpasar, Indonesia. She had finished a bachelor } \\
\text { degree at Udayana University in 2009. In 2014 she had finished Master Degree at } \\
\text { Gadjah Mada University. She is interested in psychological human resource } \\
\text { management, and also organizational behavioral. } \\
\text { Email: irmayunita@undiknas.co.id and putuirmayunita@gmail.com }\end{array}$ \\
\hline
\end{tabular}

Pemayun, A. A. G. P., Suryanata, I. G. N. P., Nurcita, I. K., \& Yunita, P. I. (2019). Economic, social and cultural changes in society due to sustainable tourism development. International Journal of Social Sciences and Humanities, 3(3), 117-127. https://doi.org/10.29332/ijssh.v3n3.359 